\title{
EXCHANGE OVER TROUBLED WATERS: THE ANIOMA AND THE WAR-TIME TRADE WITH BIAFRA, 1967-1970
}

\author{
Odigwe A. Nwaokocha'
}

(c) (i)

\section{Introduction}

The Nigeria-Biafra war was fought between the secessionist state of Biafra and Nigeria between I967 and I970. It witnessed intense struggles between the two contending parties to gain victory. Biafra struggled against many odds to survive not just militarily. This included the attempt by the Nigerian Federal Military Government to economically strangulate her, by stiffly enforcing a blockade that denied her of all goods, including food, necessary for her survival. The federal aim was to force her into surrendering and abandoning her proclaimed status as a state. Reacting to the exigency of the time, Biafra looked west and traded with the Anioma people in a way that enabled her to procure needed items. This prolonged the war with her Nigerian foe and elongated her survival. Many works exist on the Nigeria-Biafra war (Achuzia I986; Akpan 1976; Alabi-Isama 2013; Anwunah 2007; de St. Jorre I972; Madiebo I980; Obasanjo I980; Ogbemudia I99I; Okocha I994; Okocha 20I2; Tamuno and Ukpabi I989; Uchendu 2007). One was authored by a top civil servant; five by ex-soldiers; two by a journalist and two by professional historians. They said very little on the war-time economy and trade on both sides of the divide. However, a few works focused on the economies of both sides during the war (Aboyade and Ayida I971, I5-37; Adisa I984, 93-I04; Nafziger I972, 223-245; Ogbudimkpa I985; Okigbo I989, 2OI-2I2). None of these works discussed the cross-border trade between the Anioma people and Biafra during the war. Gloria Chuku (2002, 2I6-228) and Egodi Uchendu (2007, I35-I45) have, however, discussed aspects of the

I Department of History and International Studies, University of Benin. Benin, Nigeria. E-mail: odigwenwaokocha@gmail.com. ORCID: https://orcid.org/०o०o-०o०2-3947-070X. 
trans-border trade between Biafra and the Anioma. Both were restricted to the role of women in the trade. This work attempts a general examination of the trade, as it concerned the Anioma people.

It is important to point out that the old Eastern Region that seceded to form the Republic of Biafra was dominated by the Igbo ethnic group. However, a subset of the Igbo group - the Anioma - lived in a part of the Midwest Region and were not geographically part of Biafra. Many of them, however, felt culturally and historically affiliated to Biafra and so shared in the dream of Biafra and actively supported the idea. Some Anioma people were killed in the pre-war killings targeted at the Igbo in the Northern and Western regions of Nigeria that led to the separatist thinking that produced the secession and eventually, war (Agunyai 2005, Interview). Some Anioma military men (formerly of the Nigerian armed forces) crossed over to the Biafran side and fought for Biafra against Nigeria during the war (Nwaokocha 2019, I03-II9). Another aspect of their support for Biafra was that Anioma communities on the western bank of the River Niger played a key role in the economic relationship between Aniomaland and Biafra during the Nigeria-Biafra war. Starting from Ebu and Illah in the north down to the Asaba-Ase and Onyaa area to the south of Aboh, the economic survival of Biafra partially rested in the hands of a section of Aniomaland. Some other Anioma people living upland were also involved in the economic sustenance of Biafra. This was done through trade with Biafra during the Nigerian civil war. Essentially, the trade involved the movement of goods in a one-way traffic from Anioma communities on the Nigerian side across the Niger to Biafra in the east. It was a huge trade with very many dimensions. Unfortunately, the general outline of the phenomenon; the nature of the trade; the reason for it as well as its implications and meaning for Biafra, Nigeria and the Anioma people, has escaped the attention of most scholarly discourses. It is almost an uncharted territory. As shown earlier, some works have highlighted aspects of the trade. However, they are too restricted by the choice of women traders alone, and the exclusion of their male counterparts, as a tool of analysis. In delving into this field, this work hopes to add something new to our understanding of the Nigerian civil war. The trade attempted to undermine the federal blockade against Biafra and so was prohibited on Nigerian soil. It was, however, encouraged in Biafra for whom it was an aspect of continued defiance of federal authority and a vote for national survival. One of the major things about the trade is that, amongst other things, it helped to shore up the Biafran economy and prolonged the survival of Biafra.

Due to the nature of the work, this study employs oral data alongside other sources. This includes interviews focused on various facets of the trade 
in question. Oral data was obtained from interviews with nine informants between 2008 and 2012. At the time of interview, they were aged between 56 and 76 . One informant lacked primary education. Six of the informants had secondary education, while three had post-secondary education. Three were retired public servants; three were retired head teachers; two were businessmen; one was a community leader and two were traders. Two of them were women. All the informants were resident in Aniomaland during the war. All are of Anioma ancestry. Interviews were conducted in the local Igbo language and English, recorded and later transcribed.

\section{Locating Aniomaland and its People}

It is important to note that the Nigerian civil war was essentially between the Igbo ethnic group and the rest of Nigeria. Most of the Igbo in Nigeria live in the former Eastern Region, which seceded to form the Republic of Biafra on May 30, 1967. An Igbo sub-group lives outside the former Eastern Region in the previous Mid-West. They are referred to as the Anioma and the area they occupy is called Aniomaland. The two groups are separated from each other by the Niger River. The Anioma tag for the Igbo group on the western bank of the Niger has not always been used for them and the land they occupy. The name has a history of its own. In fact, it is a new term said to have been deployed for the first time to refer to the people and their land around 1976 (Okocha I994, xv).

The area known as Aniomaland lies in the middle reaches of the lower Niger River's western bank in Nigeria. It stretches from Onyaa axis in the south to Ebu in the north of the Niger Valley. Further upland and away from the Niger Valley but still on the same axis, the Anioma territory goes as far as the village of Anioma in Odiani clan. Here, the territory has a common boundary with Esanland in Edo State just like it does on the Ebu axis in the Niger Valley. In geographical terms, the relative position of the Anioma area is as follows: it is bounded in the east by the Niger River, with Anambra and Imo states located at the eastern bank of the river. The territory has a huge stretch of boundary with Edo state on its western axis. In the south-west, Aniomaland is bound by Bomadi, Isoko-South, Isoko-North and Ughelli North local government areas of Delta State. The area also shares boundaries with Edo State along its northern axis.

Modern Aniomaland has nine local government areas. These are Aniocha North, Aniocha South, Ika North and Ika East, Ndokwa East, Ndokwa 
West, Oshimili North, Oshimili South and Ukwuani. At the time of the Nigerian civil war Aniomaland had three political divisions, namely Aboh, Aniocha and Ika. Residing on the western bank of the Niger River has necessitated the Anioma people being referred to as 'West Niger Igbo' in some circles. This descriptive term was employed as a geographical phrase to differentiate them from other Igbo sub-groups, who live on the eastern bank of the Niger. At a time in their history the Anioma people were referred to as 'Western Igbo'. They have also been called 'Ika Igbo', 'Western Igbo', 'Mid-Western Igbo', 'Bendel Igbo' and presently some refer to them as 'Delta Igbo'. The idea behind their being called by these names is to differentiate them from the larger Igbo stock of the former Eastern Nigeria. This can be explained by the fact that Aniomaland was located in the Western Region between 1946 and I963; in the Midwest from I963 to I976. The Midwest was re-christened Bendel State in I976, a name she bore till I99I, when Delta State was carved out.

For most parts, Aniomaland is marked by thick rainforests laced with elegant tall palm trees. The area is also a natural home to swamps and mangrove growths in some of its dense wetlands around the Niger River. This is towards its southern extreme, particularly following the course of the Niger and its adjourning swamps as the river navigates its way to the sea. These swamps are noticeable and starts from around the Ebu and Illah in the northern tip of the territory through Asaba, the Oko clan, stretches to the Ibusa area, Olodu, Ewulu, Abala-Oshimili, Utchi, Onuaboh, Okpai, Beneku, Aboh down to the Asaba-Ase, Umuolu and Onyaa area to the south. This swampy terrain is criss-crossed by streams, brooks and rivulets, all of which are tributaries of the Niger River, into which they empty themselves. Accessing this part of Aniomaland is challenging because of its difficult terrain. In some areas, the swampy terrain stretches about five kilometers inland from the banks of the Niger. It stretches beyond that distance inland in a western direction as the Niger gets close to the sea. It manifests in such a way that around Utchi, Okapi, Beneku and Aboh, it increases in span to a range of about ten kilometres inland. This swampy terrain was critical in the trade that forms the subject-matter of this work.

Majority of Anioma people speak basically three different dialects of the macro Igbo language and two other dialects of Yoruba and Igala. Broadly these are: Enuani (made up of Oshimili and Aniocha), Ika and Ukwuani or Kwale. The various Igbo dialects of the Anioma are widespread and virtually all the Anioma people, including the Olukwumi and Igala speakers, speak and understand Igbo. So, Igbo is the general language of the Anioma. These three variants of the Anioma dialect are spoken by three broad sub-cultural entities that make up what is now seen as the Anioma group in Nigeria. Their 
identity has become the subject of many arguments (Ijomah 20IO, I3-I8). However, evidence exist that most Anioma people are of ancient Igbo stock and are regarded in very many circles as an Igbo group (Talbot I969; Isichei I976, I6; Ekechi I97I, I66-I75; Onyekpeze 2003, I4-27; Ben Nwanne 2004, 294-375; Akeh-Osu I992; Ejiofor I982; Dike I956, 25-26; Afigbo I981, I7-24; Ohadike I99I; Ohadike, I994; Dieyi 1992; Osia 2012, I-22; Egwu 2009, I8\&2I). It is instructive to know that in his classification of Igbo sub-groups and their languages, the ethnographer P. A. Talbot referred to the Anioma group and their dialects collectively as 'Ika-Igbo' (I969, 39). This and other cultural affinities between Aniomaland and the Igbo across the Niger River may well prove the hard facts of a shared and unbroken relationship between the Anioma and the Eastern Niger Igbo. Aniomaland is generally seen as a section of the larger of the Igbo culture area in Southern Nigeria. In fact, there is a strong continuity between the Anioma and the Eastern Igbo. This is only physically but not culturally punctuated by the mighty Niger River. Many Anioma people saw themselves as Igbo and other Nigeria groups saw them as such prior to and during the Nigerian civil war. When, for instance the Military Governor of the Igbo-dominated Eastern Region, Lieutenant-Colonel Chukwuemeka Odumegwu-Ojukwu proclaimed the region the independent Republic of Biafra on May 30, I967, different sections of the Anioma community both at home and abroad, erupted in joy and supported the move as long overdue (Aniedue 20I0, Interview; Otuya 20II, Interview). This explains how Aniomaland and the Anioma people came into the picture in the Nigerian civil war; fought massively on the side of Biafra and promoted a trade that sustained Biafra's yearning for essential commodities. Outside the opportunity for profits provided by the trade, the Anioma were partially involved in the trade for being who they are: an Igbo group involved in socio-cultural relations with their kith and kin across the Niger River in Biafra.

\section{The Origins of the Trade}

Prior to the declaration of hostilities on July 6, I967 that kicked-off the Biafra-Nigeria war, at the declaration of the state of Biafra on May 30 , I967; the federal military government of Nigeria had imposed an economic blockade on Biafra. This measure was stiffly implemented by federal troops during the Nigeria civil war.

It is important to note that as neighbours separated by the Niger River which presented a barrier that was bridged with canoes; the Anioma and the Igbo east of the Niger had traded for a very long time before the 
Nigerian civil war. The exigencies of the Nigerian civil war that produced the federal blockade attempted to kill-off this time-tested economic tie. In a way, people on both sides of the Niger resisted that attempt to criminalize an age-long trade that had existed across the Niger River by canoes as the Niger Bridge was only commissioned for use on December 14, I966. The federal determination to enforce the ban on economic relations between Biafra and Nigeria meant very difficult times for Biafra and her citizens. The burning and looting of the Onitsha Main Market in October I967 and the final fall of Onitsha into federal hands by March 1968 were very bad news for Biafra from an economic point of view. Onitsha was of strategic economic importance with her huge market and tonnes of goods that would have aided Biafra's war effort and eventual survival. The loss was very disadvantageous. The Midwest had traded freely with Biafra when it was under Biafran occupation starting from August 9, I967 up to October 4, when the last batch of motorized Biafran forces retreated into Biafra from the Midwest. Even when the Niger Bridge was sealed by Nigerian authorities as part of the blockade against the Eastern Region for seceding from Nigeria, the Anioma and indirectly, the Midwest traded actively with Biafra employing canoes and boats with Asaba and Onitsha as hubs. The fall of most of Aniomaland, including Asaba in September/October I967 presented new challenges that threatened Biafra's survival. When added to the loss of Bonny at the early stage of the war and Port Harcourt and Calabar subsequently, which cut off Biafra completely from the sea, her envisioned collapse became nearly palpable. As the size of Biafra shrank, her economic fortunes dwindled significantly. Something had to be done. The war-time trade under discussion was an aspect of the Biafran response to a dire situation. The need for Biafra's survival in the face of the rising scarcity of every essential commodity like drugs, soap food and clothing, made Biafrans turn to a new kind of trade with her neighbours. The Anioma people who live just across the Niger from Biafra's western border were one of such neighbours. A market in essential commodities consequently boomed across the Niger between the Anioma and their neighbours in the east. The uniqueness of the trade is underlined by the fact that it was considered illegal on the Nigerian side while it was legal on the Biafran side and so warmly embraced. This warm feeling towards the trade was shared by their Anioma neighbours to the west across the Niger. For the federal government, prohibiting economic relations with Biafra was a vital aspect of the war. For Biafra, bursting the economic blockade ringed around her by the federal government was not just about defiance. It was an intrinsic part of her struggle for statehood and survival. On the Nigerian side, where Aniomaland belonged to in the war, the trade was clandestine and conducted 
with stealth. The trade has come to be known by three interrelated names: ashia ataak (attack trade); ashia nmgbo (attack bullet trade) and ashia nmgbuka (auction trade). The word ashia in all three denotes trade as ashia, afia or ahia is the Igbo word for market, depending on the dialect of the Igbo language one chooses to deploy.

\section{The Nature of the Trade}

The trade involved ferrying essential commodities of all kinds from riverine and hinterland Anioma communities on the western bank of the Niger to their Igbo counterparts on the eastern bank of the same river. The articles of trade included food items, drugs, petroleum products, motor and machine spare parts, tobacco, cigarettes, clothing, soap, glue, stationery items and Nigerian newspapers (Oyana 2007, Interview). Both Nigerian and Biafran currencies were accepted as legal tenders.

It was a trade that involved the Anioma moving large quantities of goods in little consignments across the Niger River with the use of canoes and boats into Biafra. On the Anioma side, most of the trade was conducted over unmotorable bush tracks employing the use of bicycles and head potterage as well canoes to cross innumerable water bodies on the way even before the huge Niger River that separated Aniomaland from Biafra. Because ties with Biafra were strictly forbidden following the terms of the federal blockade against Biafra, the trade constituted illegal contact and smuggling of goods to Biafra by the Anioma. Participants in the trade conducted business in war zones and war frontlines. Bullets flew around and death was common. Oyana, who participated in the trade, remembered over ten traders who died (Oyana 2007, Interview). Olise, who was himself a trader, still remembered that five of his fellow traders were shot by federal troops (2010, Interview). The fact that the trade went with the possibility of death explains why the trade was tagged ashia ataak (attack trade) and ashia nmgbo during the war (bullet trade) in some circles as both phrases were employed as descriptive terms to capture the nature of the trade. The risky nature of the trade conducted across enemy lines and its necessity for Biafra has led Gloria Chuku into labeling it '... a life-or-death trade but a child of necessity' (2002, 220).

The communities involved in the trade on the Anioma side were Illah, Asaba, Ibusa, Ogwashi-Uku, Ewulu, Olodu, Akpako, Osisa, Iselegu, Afor, Inyi, Oko-Ogbele and Utchi. Abala-Oshimili, Abala-Unor, Obalagada, Okapi, Beneku and Aboh. In the hinterland, Obiarukwu and Agbor were 
also involved as markets for goods at the supply end. On the eastern side receiving the articles of trade were traders in Atani, Idenmili, Umunankwo and Osomala (Dike 2008, Interview).

Some of the known trade routes over which the trade was conducted are as follows: Agbor-Issele Uku-Illah and Otuocha in Biafra (Nwose 2009, Interview); Agbor-Ogwashi Uku-Ewulu, Isheagu Abala Oshimili and Atani in Biafra (Ofili 2009, Interview); Obiarukwu-Iselegu-Inyi-Utchi and Umunankwo in Biafra (Olise 2oro, Interview); and the Agbor-Issele Uku-Issele Azagba-Ibusa-Olodu-Abala Oshimili and Atani in Biafra routes (Oyana 2007, Interview). Other routes were Agbor-Ogwashi Uku-Ibusa-Oko Ogbele-Osomala (in Biafra) (Oyana 2007, Interview); Agbor-Issele Azagba-Ibusa-Oko Anala-Oko Ogbele-Osomala in Biafra (Uchendu 2007, I4I); Agbor-Issele Azagba-Okpanam-Anwai near Asaba-Ekempu and Anam (in Biafra) (Uchendu 2007, I4I) and the Obiarukwu-Utagba Ogbe-Obikwele-Okpai-Abala and Atani (in Biafra) route (Uchendu 2007, I4I). As shown by the trade routes, Agbor on the Anioma side and Atani on the Biafran side were heavily involved in the trade. However that should not be taken to mean that the routes were constant. They actually varied according to the dynamics of the war and the need to avoid federal forces on the Anioma side intent on stopping the trade. This shifting dynamics of the trade according to the intensity of the war can be gleaned from the demise of Asaba as a major emporium of the trade and the emergence of Isheagu away in the hinterland as the new hub.

The federal government's imposition of an economic blockade on Biafra meant an economic break which the federal government ferociously enforced. The Midwest regional government helped in enforcing the economic blockade (Daily Times I967, 4-5). The eventual sealing of the Niger Bridge after the May 30, I967 declaration of Biafra could not stop the trade between the Anioma and their kith and kin in the new Biafra. The two groups turned to other means to continue their trading activities. In this wise, the old and earlier abandoned Asaba wharf on the Niger that had acted as a fulcrum for river transportation between the Midwest and the East before the commissioning of the Niger Bridge that connected the two regions through Asaba and Onitsha for use, was called back into action as a trading port (Enemoh I999, 227). This trade continued unimpeded in the early stages of the war both through the wharf and mostly through the Niger Bridge, which was smashed open by Biafran forces on their invasion of the Midwest on August 9, I967 and remained open to traffic until Asaba fell to the federal forces on October 4, I967. The next day, two spans of the Niger Bridge at the Onitsha end were blown up, thus rendering the bridge unusable. It remained so until it was reconstructed in $\mathrm{I} 972$, two years after the end of the war. 
The federal military conquest of much of Aniomaland by September/ October I 967 and the expulsion of most Biafran forces from Aniomaland and the official severance commercial links between her and Biafra did not kill-off the trade. It merely changed the location of its headquarters. With the fall of Asaba and the huge presence of federal forces in the town, the town ceased to be an emporium for the trans-border trade. Security concerns pushed the trading activities into a more hidden location in the Anioma hinterland. This development created the Isheagu-Abala Oshimili-Oko Ogbele-Osomala route among others as new avenues for transporting goods into Biafra. The importance of the strategically-located Isheagu in the trade was further strengthened by the end of March ig 68 with the fall of Onitsha after three failed attempts by the forces of the $2^{\text {nd }}$ Division of the Nigerian Army under the command of Lt-Col Murtala Mohammed to capture Onitsha through the crossing of the Niger River from Asaba.

The trade was of strategic importance to the Biafrans. Their survival and that of their state was somewhat hinged on its fate. The economic blockade had ensured that Biafra lacked everything she needed to survive. Shortages of virtually all that were essential meant Biafra lived on borrowed time. As the territorial size of Biafra shrank, it got worse and the borrowed time was being deeply depleted. Biafra got into dire straits starting from March I968 as she lost almost all its key towns including Enugu and Onitsha. Due to the fact that she also faced serious military reverses on every conceivable side, the importance of the trade with the Anioma across the Niger grew. For the Biafran military, medical supplies, particularly antibiotic drugs, were of utmost importance. They were critical in the treatment of Biafra's injured soldiers. For Biafra therefore, it was a desperate situation. On the federal side, policing everywhere to ensure the blockade was ultra-effective was a major component of the general war strategy. It was a weapon of war without ammunition. Biafra needed the trade for the survival of the Biafran state and the wellbeing of her people. For her, therefore, the importance of the trade could not be overemphasized. But the trade faced daunting obstacles. The federal side needed to snuff it out in order to maintain the advantages conferred on her by the stranglehold the economic blockade imposed on Biafra.

The nature of the trade was such that people involved in it conducted trade in war zones and went to the war front sometimes to conduct the business of buying and selling. Chief Otuya mentioned that many of the traders were shot in the process (Otuya 20II, Interview). It is important to know that beyond the risk of getting shot at the war front, the terrain in which the business was conducted made it doubly risky for participants. It was a trade conducted across rivers and most times traders had to cross many rivers to 
get to desired destinations (Oyana 2007, Interview). The risk factor was quite high and getting drowned was never far-off. In fact, one Oduko of Illah was allegedly pushed off a canoe by his mates over some disagreements in the course of the trade on the Niger River. He drowned and his body was never found (Okoh 20I2, Interview). Despite the dangers involved, many Anioma youths of the era got involved in the trade. A lot of such people were shot by federal troops for aiding Biafra (Dike 2008, Interview).

\section{Anioma Motivations for Participating in the Trade}

From the point of view of winning the war through an effective economic blockade of Biafra, the federal authorities imposed the instant death penalty on anyone found trading with Biafra. The Anioma traders involved in the trade knew this. One of them recalled that some of his partners were caught in the process of ferrying goods to Biafra and were shot by federal troops (Olise 20I0, Interview). Despite this, the trade was popular and attracted huge patronage. The reason for that may not have been unconnected with the lucrative nature of the trade. According to two people who were active participants in the trade in their youth, the profit margin for the least article sold was over two hundred percent (Oyana 2007, Interview).

The attraction of huge profits reaped from the trade was partly responsible for the enthusiasm with which it was embraced by some courageous Anioma young men and women. However, while the lure of profit loomed large as a major motivation for participating in the trade, there were other push factors for the traders. Some Anioma partisans were very active in the trade, which they considered an integral part of the war. For them, the trade presented an opportunity to undermine the federal attempt to crush Biafra. It was their way of assisting fellow Igbo people across the Niger River in Biafra beat hunger, starvation and general lack occasioned by war-time exigencies (Oyana 2007, Interview; Olise 20I0, Interview). The ethnic dimension to the trade was fundamental in the fanaticism with which some of the traders pursued the trade. One would have expected that with the brutal treatment meted out to Isheagu and its inhabitants for hosting a major component of the Trans-border trade that it would have fizzled out completely out of fear of reprisal from the federal authorities. That, however, did not happen. The determination of Anioma traders to continue with the trade despite appeals from the federal army authorities was quite frustrating to the federal forces (Nigerian Observer June 8 I968, 3; Nigerian Observer July 9 I968, 3). 


\section{The Organisation of the Trade in Aniomaland}

The ashia ataak between the Anioma and Biafra was organized in such a long sequence that it took it deep beyond Aniomaland. Short of saying it was well organized, the chain of the trade ran back into the hinterland, to Benin City and Warri in two different directions. In both cases, Agbor and Obiarukwu were fundamental and lay at the middle. The 'real traders' procured most of their products from the massive war-time markets that grew in both towns. These traders who lived close to the riverine area in turn sold to Biafran who came from across the Niger. It is important to point out here that many traders crossed the Niger into the riverine areas of Aniomaland to buy goods and ferry back to Biafra. Not many Anioma traders were known to have crossed the Niger into Biafra to sell goods. It was a very powerful economic relay with articles of trade as batons. With time, particularly with the Onitsha market in ruins and following the capture of Onitsha by federal troops on March 3I, I968 after three earlier disastrous attempts, Isheagu emerged as a huge market in the trade between Aniomaland and Biafra. The fate that befell Isheagu on May 2, I968 when the town was burnt and many killed was partly due to her alleged role in the trade across the Niger (Okocha I994, I25-I27).

\section{The Trade and the Federal Attack on Isheagu}

One of the consequences of the trade and a response by the federal authorities to stop the trade was the sacking of Isheagu by federal forces. The emergence of Isheagu as a major economic hub in war-time Aniomaland is traceable to developments outside Aniomaland but not completely unconnected with her role in the Nigerian civil war. In a twist that is not easily explainable, Isheagu's emergence as a major trading depot among the Anioma people can be traced to what happened across the Niger River in Onitsha. By October I2, I967 when federal troops made their first attempt to invade Onitsha by boats from Asaba, the Onitsha Main Market became a smouldering ruin. It was looted and set ablaze by federal troops before their forced hurried retreat across the Niger to Asaba due to the stiff opposition of Biafran troops stationed at Onitsha under the command of Col. Conrad Nwawo. The destruction of the Onitsha market and the subsequent loss of Onitsha to the federals in March Ig 68 was a huge blow to Biafra's mid-section. It is doubtful if she ever recovered from that set-back. With Onitsha gone, a 
large reservoir of products that could have served as Biafra's economic shock absorber lay prostrate.

From a purely strategic survival angle, the trade in essential goods from anywhere was crucial for the survival of Biafra. Between the end of March and the beginning of May I968, Isheagu's reputation as the new market for all essentials grew and exploded to a level where it could no longer continue to be ignored by the federal army. She had emerged as the main trading focus and traders involved in the Biafran provisioning trade from both sides of the Niger flocked to Isheagu to buy and sell. Another challenge for federal troops was that while normal buying and selling of most goods that ended up across the Niger took place in day-time, the difficult canoe and bicycle ferrying away from the area of federal control and into Biafra took place over difficult terrains at night (Unoshai 2009, Interview). It was covert and well organized. The booming market at Isheagu had also, from a Nigerian perspective, become dangerous in military terms as many traders from Biafra flocked there in a way that compromised the security of federal troops stationed around there. Unknown persons suspected to be Biafran partisans had planted a bomb that killed many federal troops close to Nsukwa junction within the precinct of the community (Unoshai 2009, Interview). The Nigerian Army watched in utter consternation as these largely untowards developments unfolded. Unable to have access to the hinterland between Isheagu and the Niger because it was difficult to reach and mostly in Biafran hands, federal troops decided to take matters into their own hands. Isheagu, therefore, along with its market had to go to stop the market with all it meant to Biafra and Biafran surreptitious military presence in the area. The community was consequently attacked on May 2, I968. From a federal point of view, the attack on Isheagu was, therefore, a clampdown on some clandestine activities going on around the town. The attack on Isheagu succeeded in stopping the booming trade across the Niger with the town as a major base of operations. The market and the town itself were sacked while the town's traditional ruler was reportedly buried alive by rampaging federal forces (Okocha I994, I04). However, it did little else and failed to stop the trade from continuing. It rolled on up to the very end of the war in I970 (Olise 2010, Interview).

The sacking of Isheagu had a consequence of shifting the trade centre further inland to a more western direction to Nsukwa. This time around, traders avoided the wrecked Isheagu but still connected to an old route that passed through Abala, Oko-Ogbele to Atani that had been routed through Isheagu. This time around, federal troops could not do much as they had erroneously assumed that Iseagu was the only Anioma town that was an 
anchor of trade with Biafra (Uchendu 2007, I4I). They failed to grasp that the trade was far more diffused among the Anioma people for many reasons, including fraternal ties with Biafra, which no heavy military presence could uproot and throw into the air.

Beyond stopping the clandestine trade, the federal intention to remove Isheagu and its environs from the Biafran sphere of influence was not achieved. Biafran enclaves lay in a long stretch of land to the east of Isheagu and other neighbouring communities to the north and south. In June I968, while the Biafrans were on the offensive to regain Onitsha, they launched into that part of Aniomaland with their $\mathrm{II}^{\text {th }}$ Division under the command of Col. Ogbugo Kanu from Atani across the Niger in the East. The idea was for the force to move northwestwards to capture places like Oko, Ibusa, Ogwashi-uku and their environs (Madiebo i980, 256-259). Coming a few weeks after the sack of Isheagu and the physical destruction of a market that had ministered to the best needs of the Biafran economy and national survival, it is difficult not to imagine that those June forays into that marshy part of Aniomaland were not a Biafran attempt to keep the trade routes open and protect Biafra's over-all national interest around Aniomaland. If it was a coincidence, it is too powerful to ignore.

\section{Some Results of the Anioma War-Time Trade with Biafra}

Chief Paul Otuya informed us that in some parts of Ukwuani, the trade boomed as the area was under Biafran control for most of the war. This was particularly true of remote communities behind the Ase Creek and the Akpuke Bridge. Many residents of those communities became full-time participants in the trade and grew substantially wealthy before the war ended for their boldness and enterprise (Otuya 20II, Interview). The emergence of young men as big traders and wealthy men at the end of the war in certain Anioma communities is traceable to the inter-war trade between the Anioma people and Biafra. Chief Olise informed us that a well-known Nigerian millionaire whose name he mentioned but pleaded to be kept away from official communications worked under him and cut his teeth in business in the trade. He said his experience and accumulated wealth laid the foundation for his current status (Olise 20I0, Interview). In Ibusa, two young men who were active participants in the trade and became big time traders at the end of the war are still called Nmgbuka up to this day. This name derived from their involvement in the trade has swallowed their real names (Aniedue 20I0, Interview). 
The emergence of Boji-Boji Owa (erroneously referred to as Agbor as different from Agbor Obi) as the commercial nerve-centre of Aniomaland until Asaba emerged Delta State capital in I99I dates from the civil war and Boji-Boji Owa's role in the trade between the Anioma people and Biafra. When the Onitsha market was burnt by federal troops on I2 October, I967, Agbor was a major beneficiary of a fall-out of that incident. The point needs to be made that the demands of war made economic ties between the Anioma and the former Eastern Region more vital. The economic blockade imposed on Biafra got harsher as the war wore on and got critical with the destruction of the Onitsha market and its tons of goods that would have aided Biafra's survival deep into the war. The fall of Onitsha in March I968 made matters worse. Basic necessities of life became scarce and Biafran traders besieged the riverine areas of Anioma on the western bank of the Niger in search of goods to aid Biafra's survival. Anioma traders responded to the lure of profit by going behind the frontlines to procure needed items for Biafran traders to ferry home at exorbitant rates.

That was how Agbor came into the picture as a place for the procurement of goods for Biafra and other parts of Aniomaland during the civil war. War-time scarcity of essential items in Anioma communities to the east of Agbor and Biafra promoted trade and Agbor emerged as Anioma's biggest market during and after the war. Given her geographical location of being only a stone throw from Warri and Benin City, no other town in Anioma could compete favourably with her in the struggle for the duties thrust upon her by the war. Obiarukwu was a poor competitor because of her position of only being accessible to the Ndosimili and Ukwuani markets. Agbor enjoyed a position that aided her emergence as the prime war-time market and the post-war nerve centre of Aniomaland. The economic boom witnessed by Agbor had multiplier effects on other facets of the community's life.

\section{Conclusion}

Ashia ataak was important for Biafra as it was essential to her survival. For the federal authorities, however, stopping the trade was an integral part of winning the war. The trade, for the Anioma, represented a double-edged sword. On one hand, it puts a lot of wealth in the hands of the participants. It also promoted enterprise and commercial activities that redrew the socio-economic map of Aniomaland. On the other hand, however, it was quite ruinous as it cut short the lives of many young people who attempted to take part in the trade. Many of them died. The exact number remains unknown as no 
census of that has been conducted. Trying to stop the trade gave an entirely new complexion to the war as epitomized by the sacking of the Anioma town of Isheagu. It is arguable that the trade was a major contribution of the Anioma people to the prolongation of the life of Biafra. The bravery displayed by the Anioma in the trade was an aspect of fighting for Biafra without bearing arms. For some of them, the feeling of empathy for their Biafran kith and kin entrapped in war was a major factor. For some, the lure of fantastically huge profits was too tempting to resist. For others still, it was a combination of both.

\section{REFERENCES}

\section{Interviews}

Agunyai, Okonkwo Hypolite (Born I934), Retired Public Servant, Ibusa, April 22, 2005

Aniedue, Fidelis (Born I954), Businessman, Ibusa, Nigeria, December 26, 2010.

Dike, J.U. (Born I933), Retired Headmaster, Utagba-Ogbe (Kwale), Nigeria, August 4, 2008.

Ofili, Alice (Born I940), Trader, Isheagu, Nigeria, December 29, 2009.

Okoh, Emmanuel Ofili (Born I940), Retired Headmaster, Illah, Nigeria, December I, 2012.

Olise, Enebeli (Born I940), Rtd. Headmaster, Iselegu, Nigeria, October 30, 2010

Otuya, Paul (Born I935), Businessman, Utagba-Ogbe (Kwale), Nigeria, July 3, 2 OII.

Oyana, F.U. (Born I944), Retired Public Servant Benin City, Nigeria, November 9, 2007.

Nwose, Achasia (Born I939), Trader, Issele-Uku, Nigeria, April 8, 2009. Unoshai, Pius (Born I934), Community Leader, Isheagu, Nigeria, December 27, 2009 .

\section{Books, Articles and Others}


Aboyade, Oyetunji and Allison Ayida. I97I. "The War Economy in Perspective". Nigerian Journal of Economic and Social Studies I3, no. I, I5-37.

Achuzia, J.O.G. I986. Requiem Biafra. Lagos: Steel Equip Ltd.

Afigbo, Adiele I98r. "The Beni Mirage and the History of South-Central Nigeria". Nigeria Magazine, 37, I7-24.

Adisa, F.O. I984. "The Civil War, the Economy and Nigerian Foreign Policy". Odu, 25, 93-I04.

Akeh-Osu, C. A. I992. The History of Great Isi-Ile-Uku (Issele-Uku) Kingdom. Onitsha: Etuokwu Press.

Akpan, N. U. 1976. The Struggle for Secession: A Personal Account of the Nigerian Civil War, London: Frank Cass.

Alabi-Isama, Godwin. 2013. The Tragedy of Victory: On-the-Spot Account of the Nigeria-Biafra War in the Atlantic Theatre. Ibadan: Spectrum Books.

Anwunah, Patrick. 2007. The Nigeria-Biafra War, 1967-1970: MY Memoirs. Ibadan: Spectrum Books.

Chuku, Gloria I. 2002. "Biafran Women Under Fire: Strategies in Organising Local and Trans-Border Trade During the Nigerian Civil War". In The Nigerian Civil War and its Aftermath, edited by Osaghae, Eghosa, Ebere Onwudiwe and Rotimi T. Suberu. Ibadan: John Archers, I35-I45.

Daily Times (Nigeria). I967. May 20.

de St. Jorre, John. I972. The Nigerian Civil War, London: Hodder and Stoughton.

Dieyi, Dan Olisa. I992. The Realities and Values of the Anioma Identity. Lagos: Danfejim International.

Dike, Kenneth O. I956. Trade and Politics in the Niger Delta, London: Oxford University Press.

Egwu, Joseph Nnabugwu. 2009. "The Marginality of the Anioma in Nigeria”. Anioma Essence, I, no. 5, I8\&2I.

Ejiofor, Lambert U. I982. Igbo Kingdoms, Power and Control. Onitsha: Africana Publishers.

Ekechi, F. K. I97I. Missionary Enterprise and Rivalry in Igboland, 1857-1914. London: Frank Cass and Co.

Enemoh, John. "Groundwork History of Asaba". (Unpublished Manuscript). 
Ijomah, J. Okoro. 2010. Igbo Origins and Migrations. Nsukka: Great AP Express Publishers.

Isichei, Elizabeth 1976. A History of the Igbo People. London: Macmillan Press.

Madiebo, Alexander. I980. The Nigerian Revolution and the Biafran War. Enugu: Fourth Dimension Publishers.

Nafziger, E. Wayne. I972. "The Economic Impact of the Nigerian Civil War". Journal of Modern African Studies, Io, no. 2, 223-245.

Nigerian Observer (Nigeria). I968. June 8.

Nigerian Observer (Nigeria). I968. July 9.

Nwanne, Ben. 2004. Ika: The Land and its People, Lagos: Up and Doing Publishers.

Nwaokocha, Odigwe A. 20I9. "Biafran Enclaves and Militia Activities in Mid-Western Nigeria, I967-I970”, Igbo Studies Review, no. 7, IO3-II9.

Obasanjo, Olusegun. I980. My Command: An Account of the Nigerian Civil War, 1967-1970. Ibadan: Heinemann.

Ogbemudia, S.O. I99I. The Years of Challenge. Ibadan: Heinemann.

Ogbudimkpa, R.N. I985. The Economics of the Nigerian Civil War and its Prospects for National Development, Enugu: Fourth Dimension Publishers.

Ohadike, Don C. I991. Ekumeku Movement: Western Igbo Resistance to British Conquest of Nigeria, 1883-1914, Athens Ohio: Ohio University Press. .I994. Anioma: A Social History of the Western Igbo People, Athens, Ohio: Ohio University Press.

Okigbo, P.N.C. I989. "The Economics of the Civil War: The Biafran Experience". In Nigeria Since Independence, The First 25 Years: The Civil War Years, edited by Tamuno, T.N. and S. C. Ukpabi Ibadan: Heinemann Educational Books, 20I-2I2.

Okocha, Emma. I994. Blood on the Niger: An Untold Story of the Nigerian Civil War, Washington DC: U.S.A. Africa. 2012. Blood on the Niger: The First Black-On-Black Genocide. New York: Gomslam Books.

Onyekpeze, F. A. 2003. An Outline of the Culture and Socio-Economic Interest of the Ika Nation, Agbor: Krisbec Publications. 
Osia, Kunirum. 2012. "Anioma Ethnic Identity". Anioma in Contemporary Nigeria: Issues of Identity and Development, edited by Osia, Kunirum. Ibadan: Bookbuilders, I-22.

Talbot, P. A. I969 edn. Peoples of Southern Nigeria (4 Vols.), London: Frank Cass.

Uchendu, Egodi. 2007. Women and Conflict in the Nigerian Civil War, Asmara, Eritrea: Africa World Press.

\begin{abstract}
A lot has been written on the Nigeria-Biafra war which lasted from ig67 to 1970 . However, little attention has been given to a very important but almost forgotten part of that war. This is the trade that took place between the Anioma people on the Nigeria side and Biafrans across the Niger River. It has been called the 'ashia attack'. The trade played a very important role in prolonging the survival of Biafra as essential commodities were ferried across the Niger in a trade that proved very lucrative for traders on both sides. The trade was labelled clandestine because it was forbidden by federal authorities while it was encouraged by Biafran authorities hemmed in and challenged by the economic blockade ringed around her by the former. The neglect of this important phenomenon in the Nigeria-Biafra war, particularly from an Anioma perspective, represents a void that needs to be filled if some finer details of the war are to be understood. It is important in helping glue some facts together to make for a deeper explanation of aspects of the war. In undertaking this task and employing mostly oral sources, this paper highlights and discusses the dynamics of the trade; its larger significance in the Nigeria-Biafra war that pitched the Igbo population of Nigeria against the other Nigerian ethnic groups as well as the consequences of the trade for the Anioma.
\end{abstract}

\title{
KEYWORDS:
}

Anioma. Mid-West. Nigeria-Biafra war. Cross-Border Trade. Ashia Ataak.

Received on May 3, 2021 Accepted on June 24, 2021 